\title{
11. Responsible media: Learning to survive the world's difficult, remote and hostile environments
}

\section{ABSTRACT}

What should be considered 'adequate' preparation and support for journalists and media workers in difficult, remote and hostile environments? One would assume there would be numerous sources of feedback and contributions measuring the suitability of the training, as well as providing information regarding what improvements are necessary to ensure journalists are provided the best possible pre-deployment preparation. However, after working and observing developments in this area over several years, three main issues have presented themselves. First, there is little investigation or analysis being conducted into these training programmes. Second, there are few independent organisations working to standardise the training and support provided to journalists. Finally, the extent of training and support to the local correspondents, fixers and stringers in developing countries, that most international media organisation depend on in these locations, has become an unfortunate casualty of shrinking international news budgets.

Keywords: duty of care, fixers, hostile environments, journalism education, safety training, stringers

SHAUN FILER

Dynamiq Training Consultants

W

HAT should be considered 'adequate' preparation and support for journalists and media workers in difficult, remote and hostile environments? One would assume there would be numerous sources of feedback and contributions measuring the suitability of the training, as well as providing information regarding what improvements are necessary to ensure journalists are provided the best possible pre-deployment preparation. However, after working and observing developments in this area over 
several years, three main issues have presented themselves. First, there is little investigation or analysis being conducted into these training programmes. Second, there are few independent organisations working to standardise the training and support provided to journalists (1). Finally, the extent of training and support to the local correspondents, fixers and stringers in developing countries, that most international media organisations depend on in these locations, has become an unfortunate casualty of shrinking international news budgets. With this in mind, there are clear opportunities for further cooperation between media and training organisations to ensure that duty of care

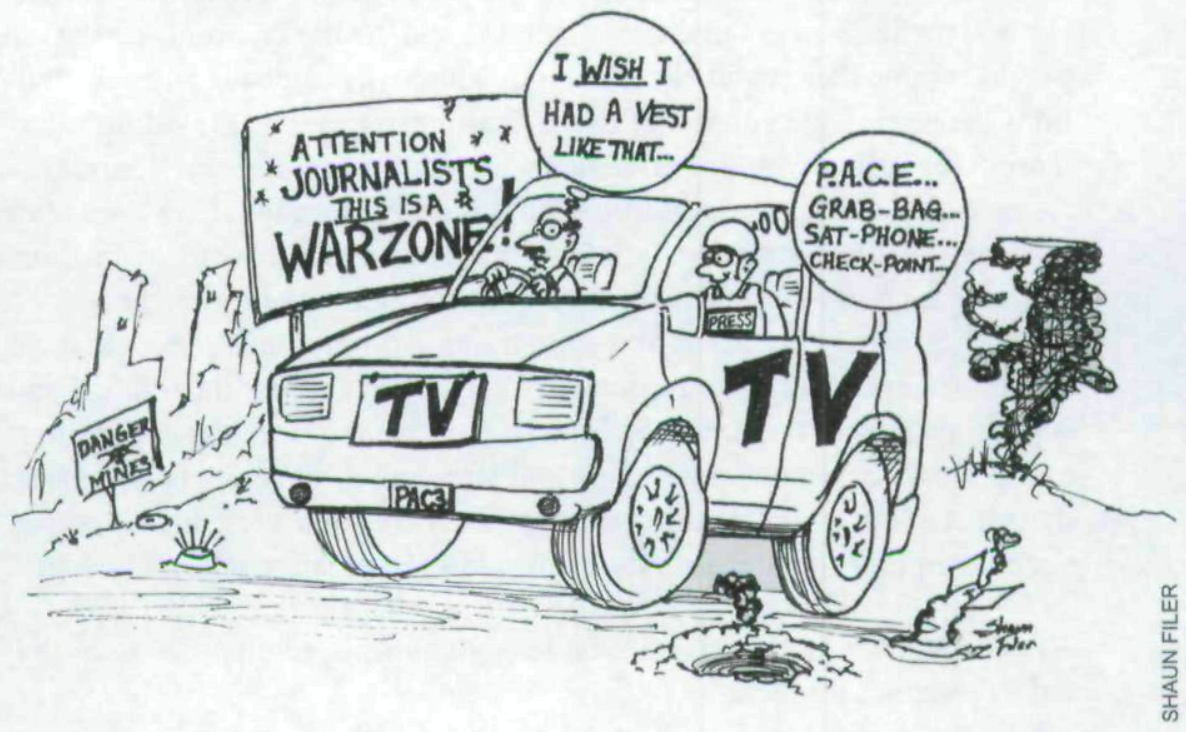

obligations are met with the budgets available. Indeed, such a cooperative between responsible media organisations is likely the most effective approach in the provision of training for local journalists and support staff.

\section{Duty of care}

The requirements for hostile environment and safety training are measured and provided by various international organisations that work to defend press freedom and protect journalists. These organisations include the International Federation of Journalists (IFJ), the Dart Centre for Journalism and Trauma, Reporters Sans Frontières (RSF), the Committee to Protect 
Journalists (CPJ) and the International News Safety Institute (INSI). These groups work to establish what 'standard of care' currently exists with respect to training and support across various media organisations, and to promote training of journalists in developing countries.

The IFJ was one of the first organisations to establish a policy towards media organisations that are not seen to be meeting a minimum 'duty of care' to their personnel. It has 'condemned media organisations which contribute to the perilous situation of journalists by unprofessional activity, excessive competition and a failure to provide resources for the training and protection of journalists' (IFJ, 1998). This clearly shows that those failing in the basic support of their staff are negligent, and are condemned in the eyes of their peers.

Aidan White, general secretary of the IFJ, has also initiated programmes to train journalists in the world's most hostile environments, noting that 'safety training is of paramount importance for the protection of journalists in high risks locations such as Iraq. We are delighted that our colleagues in Iraq were able to learn skills which will stand them in good stead in their work' (IFJ, 2009). However, there are many that remain unsatisfied with the limited resources available for this training, and what is viewed as a 'culture of neglect' towards freelancers. The international organisations facilitating the aforementioned training have a great number of issues to acknowledge in the development of a comprehensive training approach, as pointed out by this unnamed Iraqi journalist:
How did you choose those Iraqi journalists? I'm one of them and no-one informed us or advertised about this training course ... Unfortunately many good meetings, trainings and conferences are taking place in Baghdad and most of the time only the official journalists are invited (no independent journalists, reporters, or freelancers) ... I really wonder why? (IFJ, 2009)

It is appreciated that most mainstream media organisations now provide preparation, equipment and support (including psychological resilience support), but there is a lack of a 'duty of care' towards local staff, which often leaves these media workers and support staff wanting.(2) Organisations do exist which have taken initiative in this area, and 'since the mid-1990s, CNN International has provided hostile-environment training to all of its workers, including fixers, going into potentially dangerous situations' (Witchel, 
2004). Reuters News and the $A B C$ also work to train their fixers, stringers, drivers and support staff on location.

There is an 'ethical' duty of care on the part of media organisations to all employees, from correspondent to fixer. Although individual media organisations are working to improve the conditions and support provided to local employees, there should now be a concerted and organised effort to find a costefficient method to provide 'authorised' training in more developing countries and regions. The development of 'authorised' training must require an intimate understanding of the types of unique risks that journalists encounter whilst pursuing 'the story'. The nature of journalistic practice often entails moving towards the risks or potentially dangerous situations (natural disaster, civil unrest, conflict), and in recent decades more and more journalists have been targeted because of their work. 'It's certainly no protection and it's likely that you're more of a target if people see you are a journalist' (Campbell, 2008).

During my tenure of completing academic research in this area, I conducted dozens of interviews with experienced correspondents for a documentary film, and was also involved with conducting managing hostile environment training with the Australian based training and risk management firm, Dynamiq. The training is developed using current and relevant case studies from working journalists and covers key concepts across a number of events that journalist may experience in the field. The motive is to take the time with each member and make them as self sufficient, able to put risks into context and make more informed decisions about their safety. One unique feature of managing hostile environment training is the focus of assignment planning and preparation, so the journalist makes conscious decisions about potential risks and considers safety early in the process.

\section{'P.A.C.E. yourself before you go'}

This is the training pneumonic that was developed to ensure key safety elements are considered before departure to a difficult, remote or potentially hostile assignment. P.A.C.E. stands for:

P: PLAN \& PACK - Spend time developing and communicating your plan to everyone in the team, and ensure you always have a "grab-bag" with safety items.

A: ACCOUNTABILITY ALWAYS - Ensure your field-support or trusted contacts know where you are, where you going and when you intend to return. 
Increasing accountability ensures that a timely response occurs if you are involved in an incident.

C: COMMUNICATION - The most important component of your safety while on assignment is being able to effectively communicate at all times. Working communications with at least one contingency, or back-ups, is considered a minimum standard when working in these environments.

E: EMERGENCY AND EXITS-Ensure you know what to do and who to contact in an emergency, and when in doubt - know your way out.

\section{Cooperation}

It is clear that most media organisations work to develop close relationships with the training and security firms that have facilitated their courses. An opportunity exists to develop a cooperative amongst responsible media organisations to network with a core group of training professionals, thus ensuring that training opportunities are provided to local stringers, fixers and support staff that are generally called upon in such locations.

Dynamiq is currently conducting a global training initiative, which has recently included training in Afghanistan and Pakistan, where Managing Hostile Environment (MHE) courses are conducted through sponsorship, participants receive grading based on capabilities (including course results, known languages, driving ability, etc), and profiles for each individual (including their work history, media experience and available equipment), are produced for use by inquiring media organisations. Under this initiative, sponsoring media organisations receive a profile for potential local staff, and are assured that the individual in question, be it a stringer, fixer or driver, has received adequate training, is knowledgeable of general working guidelines, and has access to support and advice. This increased preparation and accountability works to provide a single source global network for responses to breaking stories, or increased support of media personnel in any region of the world.

There is a duty of care for media organisations to train, advise, monitor, protect and respond to incidents that may affect their journalists or staff working in difficult, remote and hostile environments. The value of adequately 'looking after' your people in the field means they are likely to have longer and more successful careers. They are often more efficient at filing and sending product under difficult circumstances. Beyond the immediate benefits of preparing journalists for these environments, the sponsorship of global media 
development, training and support programmes also ensures that both ethical and legal duty of care requirements are met. Ensuring that employees have received a Managing Hostile Environment course should be enforced as the minimum operating standard. These courses have saved lives in the past and they provide journalists with the tools to 'cover the story, and not become the story'.

Courses like this are great, you have to be more aware, more careful. It's not going to protect us all, but it IS a start. This year, ' $\mathrm{X}$ ' number of journalists are going to die. I know that. We are in the line of fire, very much so, I feel that on the job, and you see, year by year, more journalists are killed. (Williams, 2008)

\section{Notes}

1. Organisations such as the Committee to Protect Journalists (CPJ) and Reporters Without Borders (RWB) have released company lists for facilitators of hostile environment training, and have published their own training handbooks. However, no formal critical review of course content has been conducted.

2. Mainstream - pertains to major media organisations and their staff, which has worked to coin the phrase, 'mainstream correspondent'. The journalists that often work from story-to-story are referred to as 'freelancers', 'stringers' and 'independents'.

\section{References}

Azimi, Y. (2009, January 18). On camera: Suicide attacks and media workers in Kabul. Personal interview.

Burden of Bearing Witnss: with Philip Williams. (2007, June 17). Compass, Australian Broadcasting Corporation.

Campbell, E. (2005). Absurdistan: A bumpy ride through some of the world's scariest, weirdest places. Sydney: Harper Collins Publishing.

Campbell, E. (2007, August 02). On camera: Absurdistan (ABC). Personal interview. Carlson, M. (2006). War journalism and the 'KIA journalist': The cases of David Bloom and Michael Kelly, Critical Studies in Media Communication, 23(2), 91-111.

Cave, P. (2008, April 20). On Camera: Increased risk of working abroad, and the importance of hostile environment training $(\mathrm{ABC})$. Personal interview.

Cookes, T. (2008, October 16) Off camera: Working in Israel and journalists as targets $(\mathrm{ABC})$. Personal interview. 
Dhumières, M. (2008). Survival training: The hostile environments course that is saving reporters' lives. Retrieved 20 November 2008, from www.independent. co.uk/news/media/survival-training-the-hostileenvironments-course-that-issaving-reporters-lives-872648.html.

Doelling, O. (Ed.). (2005). Handbook for international correspondents. New York: The Associated Press.

Dunn, S. (2008, April 22). On camera: Managing hostile environments-Giving advice, monitoring, protecting and responding to incidents (Dynamiq). Personal interview.

Dunn, S. (2008). Managing hostile environments course. Attended on 22 April 2008. Fiddler, R. (2006). Mark Willacy: Middle East correspondent, ABC Features. Retrieved on 25 April 2007, from www.abc.net.au/.../stories/s1714738.htm

Forbes, H. (2007, July 08). On camera: ABC policies and procedures (ABC). Personal interview.

Fox, D. (2008, October 13). Off camera: Afghanistan and other hostile environments (Reuters). Personal interview.

Goodman, A., \& Pollack, J. (1997). The world on a string: How to become a freelance foreign correspondent. New York: Henry Holt and Company.

Handbook for Journalists. (2005). Guide pratique anglais (10:11 ed.), Paris: Reporters Without Borders.

Hill, T. (2007, July 09). On camera: ABC policies and procedures for international news and current affairs $(\mathrm{ABC})$. Personal interview.

IFJ (International Federation of Journalists). (1998). Congress 1998: Safety of journalists. Retrieved on 20 February 2008, from www.ifj.org/en/articles/ifj-congress1998-safety-of-journalists.

IFJ (International Federation of Journalists). (2009). Safety boost for media in Iraq as 45 journalists complete training course. Retrieved on 20 February 2009 , from www.ifj.org/en/articles/safety-boost-for-media-in-iraq-as-45-journalists-complete training-course.

Leach, W. (2007). 'Killing the messenger': Journalists at risk in modern warfare Parametres: US Army War College, 37(1), 146-148.

McMahon, C. (2008, January 1). On Camera: Psychological resilience (DART Centre). Interview.

McMahon, C. (2008). Lecture. Bulding mental fitness for hostile environments. Melbourne: DART Centre, Melbourne.

Osofsky, H.J., Holloway, H., \& Pickett, A. (2005). War correspondents as responders: Considerations for training and clinical services. Psychiatry-Interpersonal and Biological Processes, 68, 283-293.

Page, T. (2007, June 18). On camera: War time photography and the power of the image (Degree South). Personal interview.

Palmer, T. (2008, July 08). On camera: Work in the Middle East covering the tsunami and Ache, and the importance of preparation and planning (ABC). Personal Interview. 


\section{REPORTING WARS}

Powell, R. (2006). Journalist deaths reach record high in 2006. Greatreporter. com Retrieved on 25 April 2007, from http://greatreporter.com/mambo/index2/ php?option=com.

Robertson, P. (1999). The CNN effect: Can the news media drive foreign policy? Review of International Studies, 25, I, 301-9.

Smith, P. (2008, October 13). On camera: Editors and media managers - Duty of care and organisational responsibilities for staff in hostile environments (Reuters). Personal interview.

Smyth, F. (2003). On assignment: Covering conflicts safely. Committee to Project Journalists: Safety Handbook. Retrieved on 25 April 2007, from www.cpj.org/ Briefings/2003/ safety/safety.html\#touch.

Tumber, H., \& Webster, F. (2006). Journalists under fire: Information war and journalistic practices. London: Sage Publications.

Willacy, M. (2007). The view from the valley of Hell. Sydney: Pan MacMillan.

Willacy, M. (2008, June 02). On camera: The Middle East-planning and fixers (ABC). Personal interview.

Williams, P. (2008, April 20). On camera: Hostile environment training - Journalists under fire and psychological resilience (ABC). Personal interview.

Witchel, E. (2008). The fixers. Retrieved on 10 November 2008, from http://cpj.org/ reports/2004/01/fixers.php

Shaun Filer is a senior international security and travel risk management consultant with the Australian-based security firm, Dynamiq. He currently develops and facilitates Managing Hostile Environment (MHE) courses for several global media organisations and freelance journalists working throughout Asia and Africa, and guest lectures at Australian universities on the importance of preparation for journalists and the duty-of-care responsibilities of media organisations. He has extensive experience in media safety and security related international incident management, holds a post-graduate degree in journalism and is a documentary film maker. Before entering journalism, Filer worked in emergency medicine for eight years as a Hospital Corpsman (Medic), with the US Marine Corps. Filer's Masters thesis was entitled 'Journalists and Media Workers: Learning to Survive the World's Difficult, Remote and Hostile Environments'.

sfiler@dynamiq.com.au 
Copyright of Pacific Journalism Review is the property of Auckland University of Technology and its content may not be copied or emailed to multiple sites or posted to a listserv without the copyright holder's express written permission. However, users may print, download, or email articles for individual use.

http://www.aut.ac.nz/depts/commstud/journ/pjrsubs.shtml 